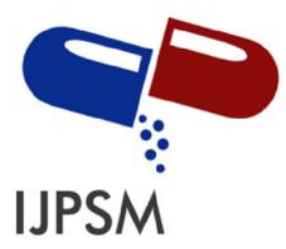

Silky Agrawal et al, Int. Journal of Pharmaceutical Sciences and Medicine (IJPSM),

Vol.6 Issue. 10, October- 2021, pg. 26-36

ISSN: 2519-9889

Impact Factor: 3.426

\title{
METHOD DEVELOPMENT AND VALIDATION FOR THE SIMULTANEOUS DETERMINATION OF AZELNIDIPINE AND TELMISARTAN IN TABLET DOSAGE FORM BY RP- HPLC
}

\author{
Silky Agrawal; Tahir Nizami \\ Smriti College of Pharmaceutical Education, IndoreMR-11, Dewas Naka, Indore-452010 (M.P.) \\ DOI: 10.47760/ijpsm.2021.v06i10.003
}

\begin{abstract}
A simple, accurate and precise method for the simultaneous determination of azelnidipine and telmisartan in bulk drug and pharmaceutical dosage has been developed by RPHPLC method. Separation was performed on a Hyperchrom ODS C18 HPLC Column $(250 * 4.6 \mathrm{~mm})$ column and Buffer $0.05 \mathrm{M}$ Potassium dihydrogen orthophosphate $\left(\mathrm{KH}_{2} \mathrm{PO}_{4}\right)$ Buffer ( $\mathrm{pH}-4.0)$ : Methanol (60:40) as a mobile phase, at a flow rate $1 \mathrm{ml} / \mathrm{min}$ and UV detection wavelength $215 \mathrm{~nm}$. The calibration of the method was performed by concentration range of $20-60 \mu \mathrm{g} / \mathrm{ml}$ for telmisartan and $40-120 \mu \mathrm{g} / \mathrm{ml}$ for azelndipine. The validation of proposed method was carried out for accuracy, precision, ruggedness, specificity for both alzenidipine and telmisartan the method can be used for routine quality analysis of titled drugin tablet formulation.
\end{abstract}

Keywords: Azelnidipine, Telmisartan, RP-HPLC Method validation. 


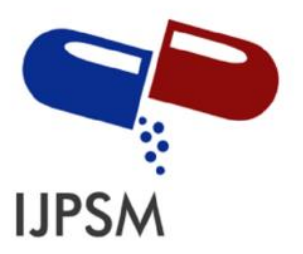

Silky Agrawal et al, Int. Journal of Pharmaceutical Sciences and Medicine (IJPSM), Vol.6 Issue. 10, October- 2021, pg. 26-36

ISSN: 2519-9889

Impact Factor: 3.426

\section{INTRODUCTION:}

Azelnidipine is dihydropyridine derivative and chemically 3-[1-(Benzyldrylazetidin-3-yl] 5isopropyl- 2- amino-6-methyl-4-(3-nitrophenyl)-1,4-dihydropyridine-3,5dicarboxylate. Azelnidipine category is Dihydropyridine calcium channel blocker. Azelnidipine calcium channel blocker. Azelnidipine inhibits trans- membrane $\mathrm{Ca}^{2+}$ influx through the voltage dependent channels of smooth muscles in vascular walls.<smiles>CC1=C(C(=O)OC(C)C)C(c2cccc([N+](=O)[O-])c2)C(C(=O)OC2CN(C(c3ccccc3)c3ccccc3)C2)=C(N)N1</smiles>

Fig: 1. structure of Azelnidipine

\section{Telmisartan:}

Telmisartan is chemically 2-(4-\{[4-methyl-6-(1- benzodiazol-1-yl] methyl $\}$ phenyl) benzoic acid It is an angiotensin receptor blocker (ARB) that shows high affinity for the angiotensin II (Ang II) type 1 (AT1) receptors, features a long duration of action, and has the longest half-life of any Angiotensin receptor blockers (ARBs). In addition to blocking the reninangiotensin system (RAS), telmisartan acts as a selective modulator of peroxisome proliferatoractivated receptor gamma (PPAR- $\gamma$ ), a central regulator of insulin and glucose metabolism. 


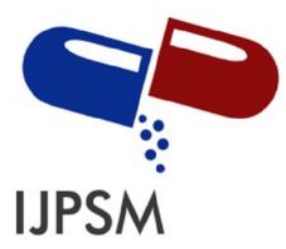

Silky Agrawal et al, Int. Journal of Pharmaceutical Sciences and Medicine (IJPSM), Vol.6 Issue. 10, October- 2021, pg. 26-36

ISSN: 2519-9889

Impact Factor: 3.426<smiles>CCCc1nc2c(C)cc(C3=Cc4ccccc4C3C)cc2n1Cc1ccc(-c2ccccc2C(=O)O)cc1</smiles>

Fig: 2. structure of Telmisartan

\section{MATERIALS AND METHODS:}

\section{Instrumentation:}

The instrument used was a dual visual display of UV Shimadzu UV1700 and similar quartz cells. The glassware used in each procedure was soaked overnight in a mixture of chromic acid and sulfuric acid that was thoroughly washed with double-boiled water and dried in a hot air oven before use. The reference absorption concept and test solution were performed in a single quartz cell at a UV range of $200-400 \mathrm{~nm}$.

\section{Chromatographic Conditions}

Separation was carried out with a Hyperchrom ODS C18 Column $(250 * 4.6 \mathrm{~mm})$ column and Buffer 0.05M Potassium dihydrogen ortho phosphate Buffer (pH-4.0): Methanol (60:40) as a mobile phase, at a flow rate $1 \mathrm{ml} / \mathrm{min}$. The UV detector was set at a wavelength of $215 \mathrm{~nm}$. An injection volume of $20 \mu 1$ was used.

\section{Chemicals and Reagents:}

Azelnidipine and telmisartan in combination TELMA-AZ (claimed labeled amount 8mg AzL and $40 \mathrm{mg}$ TEM per tablet) was procured from local pharmacies. HPLC-grade methanol was used and all other chemicals (analytical grade) were used. Azelnidipine and Telmisartan in pure form was donated as a gift samples from Glenmark Pharmaceutical Ltd Mumbai. 


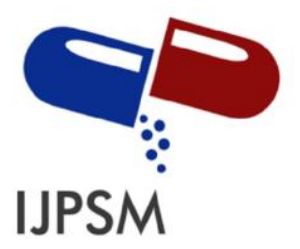

Silky Agrawal et al, Int. Journal of Pharmaceutical Sciences and Medicine (IJPSM), Vol.6 Issue. 10, October- 2021, pg. 26-36

ISSN: 2519-9889

Impact Factor: 3.426

\begin{tabular}{|l|l|l|}
\hline S.No. & Chemicals/Reagents & Make/grade \\
\hline 1 & Pottasium dihydrogenortho phosphate & Merck(HPLC Grade) \\
\hline 2 & Orthophosphoric acid & Merck(AR Grade) \\
\hline 3 & Methanol & HPLC Grade \\
\hline 4 & Water & HPLC Grade \\
\hline
\end{tabular}

Table 1: Chemical requirement

\section{EXPERIMENTAL METHOD:}

\section{Preparation of Stock solutions:}

Stock solution of Alzenidipine and telmisartan were prepared by weighing $40 \mathrm{mg}$ of telmisartan and $8 \mathrm{mg}$ of Alzenidipine and by dissolving separately in aqueous methanol in $100 \mathrm{ml}$ calibrated volumetric flask and volume was made up to the mark with methanol. Further dilutions were carried out to get the final concentration of $40 \mu \mathrm{g} / \mathrm{ml}$ of telmisartan and $8 \mu \mathrm{g} / \mathrm{ml}$ of alzenidipine further dilutions was made. Separate standard calibration graphs were constructed for each component by plotting the peak area of the drug to the drug concentration.

\section{Formulation:}

Twenty tablets, labeled as containing $8 \mathrm{mg}$ of Azelnidipine, and $40 \mathrm{mg}$ of Telmisartan together with excipients, were accurately weighed (440mg), and finely powdered. A weight of the powder equivalent to one tablet content was accurately weighed, transferred into a $100 \mathrm{ml}$ calibrated flask, diluted with methanol and sonicated for $15 \mathrm{~min}$ for complete dissociation of the drug, and made up to the mark with methanol. The solution was filtered through 0.5 Water alliances filter paper and the filtrate was collected in a clean flask. After 


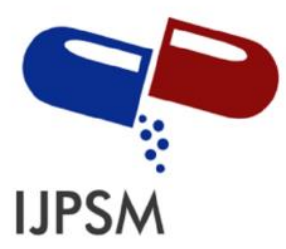

Silky Agrawal et al, Int. Journal of Pharmaceutical Sciences and Medicine (IJPSM), Vol.6 Issue. 10, October- 2021, pg. 26-36

ISSN: 2519-9889

Impact Factor: 3.426

filtration, $1 \mathrm{ml}$ of the above solution was withdrawn and diluted to $10 \mathrm{ml}$ with methanol to get final concentration of $8 \mu \mathrm{g} / \mathrm{ml}$ of $\mathrm{AzL}$ and $40 \mu \mathrm{g} / \mathrm{ml}$ of TEM. The solution was filtered through a membrane filter $(0.22 \mu \mathrm{m})$ sonicated for degas.

\section{Ruggedness, Accuracy and Precision:}

The ruggedness(intra-day, inter-day, different analyst), specificity, precision and accuracy of the methods were estimated by assaying three replicate samples at three different concentrations, on the same day and on three different days . For checking the ruggedness and precision of the method, the relative standard deviations (RSD) were calculated and tabulated. The accuracy of the methods was expressed as percentage .Accuracy of the methods was also determined by recovery studies.

\section{RESULTS AND DISCUSSION:}

This method provides a simple procedure to determine simultaneously the concentration of Azelnidipine and Telmisartan in bulk drugs and pharmaceutical dosage forms. To develop a rugged and suitable LC method, various mobile phase compositions, flow rate and different temperatures were tested.

\section{Different trials of chromatographic conditions:}

\begin{tabular}{|c|c|c|c|}
\hline Sample number & Mobile phase & $\begin{array}{c}\text { Retention time of } \\
\text { Azelnidipine }\end{array}$ & $\begin{array}{c}\text { Retention time of } \\
\text { Telmisartan }\end{array}$ \\
\hline 1 & $50: 50$ & 1.9 & 4.0 \\
\hline 2 & $40: 60$ & 1.7 & 2.4 \\
\hline 3 & $60: 40$ & 4.28 & 6.4 \\
\hline
\end{tabular}

Table 2: Different trials of chromatographic conditions 


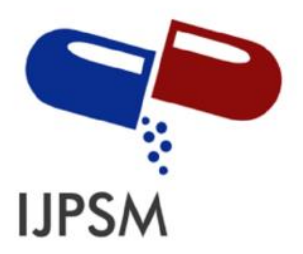

Silky Agrawal et al, Int. Journal of Pharmaceutical Sciences and Medicine (IJPSM), Vol.6 Issue. 10, October- 2021, pg. 26-36

ISSN: 2519-9889

Impact Factor: 3.426

\section{Chromatographic conditions:}

The following chromatographic conditions w ere established by trial and error and were kept constantthroughout method.

\begin{tabular}{|l|l|l|}
\hline S.No. & Chromatographic Parameters & \multicolumn{1}{c|}{ Result } \\
\hline 1. & Column & Hyperchrom ODS C18 column $(250 * 4.6 \mathrm{~mm})$ Partical \\
\hline 2. & Size Packing & Size packing : $\mu \mathrm{m}$ \\
\hline 3. & Stationary Phases & C18 \\
\hline 4. & Mobile Phase & $\begin{array}{l}\text { Buffer (Potassium Phosphate, } \mathrm{pH} 4.0): \text { Methanol } \\
(60: 40) \text { Detection }\end{array}$ \\
\hline 5. & Wavelength & $215 \mathrm{~nm}$ \\
\hline 6. & Flow Rate & $1.0 \mathrm{ml} / \mathrm{min}$. \\
\hline 7. & Temperature & \\
\hline 8. & AmbientSample Size & $20 \mu \mathrm{l}$ \\
\hline
\end{tabular}

Table 3: Chromatography parameter and result

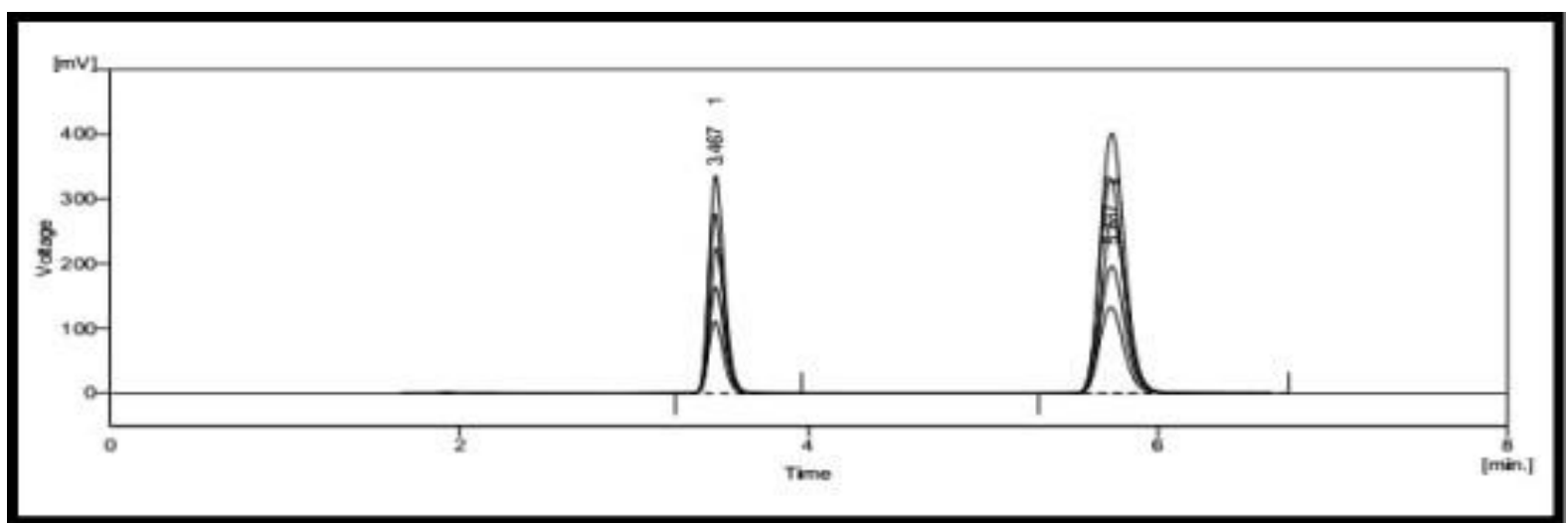

Figure 3: Final optimize condition spectra of Telmisartan and Azelnidipine

The USP suggests that system suitability tests to be performed prior to analysis. The parameters include tailing factor, capacity factor, theoretical plate number, retention time, asymmetric factor, and selectivity and RSD \% of peakheight or area for repetitive injections. 


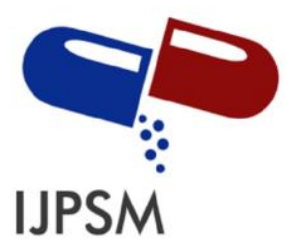

Silky Agrawal et al, Int. Journal of Pharmaceutical Sciences and Medicine (IJPSM), Vol.6 Issue. 10, October- 2021, pg. 26-36

ISSN: 2519-9889 Impact Factor: 3.426

Typically, a minimum of two of those criteria are required to demonstrate system suitability for the proposed method. Some of tests were carried out on freshly prepared standard solutions. Tailing factors of 1.5 and 1.8 were obtained for AZL and TEM respectively, with asymmetry factors of 1.24 and 1.34 for AZL and TEM respectively. The chromatographic conditions described ensured adequate retention and resolution for both of the analytes. The retention times of AZL and TEM were 5.69and $3.44 \mathrm{~min}$. the variation in retention time for five replicate injections of two compounds reference solutions gave RSDs of $0.0688 \%$ for AZLand $0.098 \%$ for TEM. The results obtained from the system suitability tests satisfy the USP requirements. The calibration curve and equations for AZL and TEL in the mobile phase was calculated by plotting the peak area ratio of compound to is vs. concentration of compound in the range of $20-60 \mu \mathrm{g} / \mathrm{ml}$ and $40-120 \mu \mathrm{g} / \mathrm{ml}$ for AZL and TEM in figure 2 and figure 3 respectively.

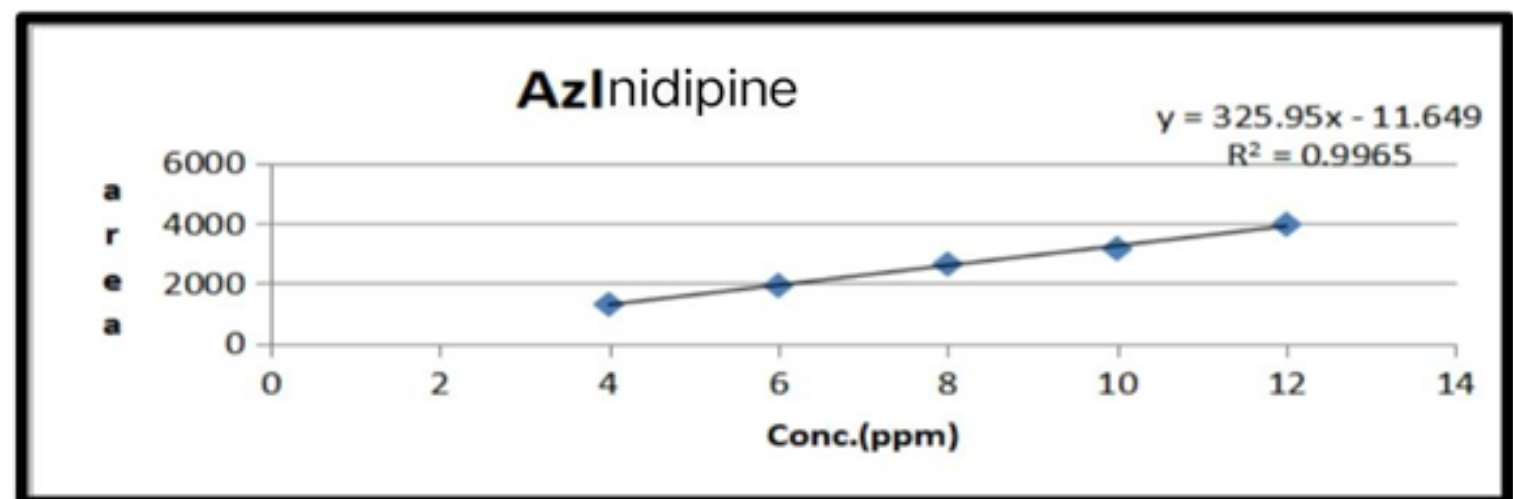

Fig No 4: Standard calibration curve for AzL

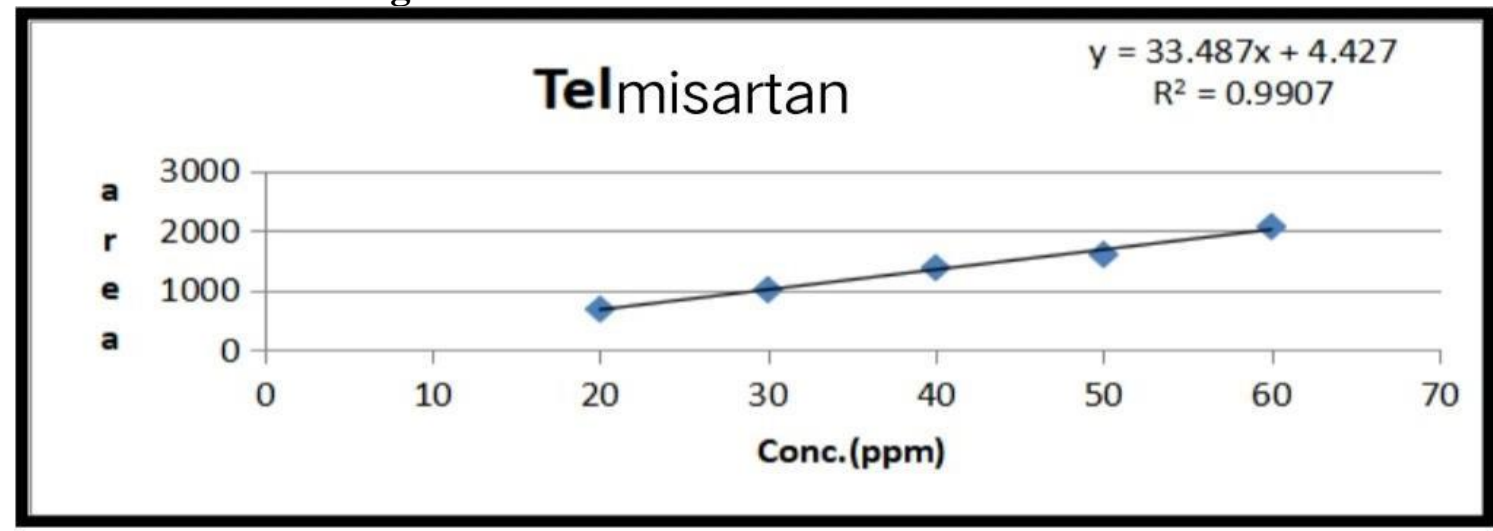

Fig No 5: Standard calibration curve for TEL 


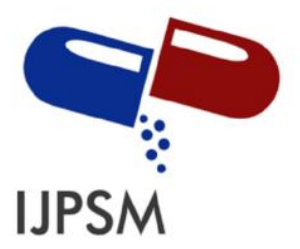

Silky Agrawal et al, Int. Journal of Pharmaceutical Sciences and Medicine (IJPSM), Vol.6 Issue. 10, October- 2021, pg. 26-36

ISSN: 2519-9889

Impact Factor: 3.426

\section{System Suitability:}

System suitability is a pharmacopoeial requirement and is used to verify, whether the resolution and reproducibility of the chromatographic system is adequate for analysis to be done. The tests were performed bycollecting data from five replicate injections of standard solutions.

\section{Parameters of System Suitability}

\begin{tabular}{|c|c|c|}
\hline Parameters & Telmisartan & Azelnidipine \\
\hline Retention time (min) & 3.440 & 5.693 \\
\hline Theoretical plates & 7016 & 7316 \\
\hline Asymmetry & 1.348 & 1.243 \\
\hline Resolution & \\
\hline
\end{tabular}

Table 4: Parameters of System Suitability

\section{Validation:}

Validation is normally done to assure the reliability of the proposed method and was performed as per the ICHguidelines for the following criteria.

1) Accuracy - Accuracy of the proposed method was ascertained from the recovery studies by standardaddition method.

2) Precision - Replicate estimation of tablet analyzed by the proposed method has yielded quite consistent resultindicating repeatability of method. Study showed \pm S.D. $<2$.

3) Specificity - Studies shows that there is no interference of peak from the component of matrix showingretention time for TEM $3.44 \mathrm{~min}$. and AZL $5.69 \mathrm{~min}$.

4) Ruggedness - Studies were carried out only for the two different parameters like different time, different dayand different analyst. Results of estimation by proposed method are very much similar under variety of conditions. This study signifies the ruggedness of the method under varying condition of its performance. 


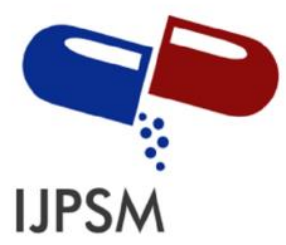

Silky Agrawal et al, Int. Journal of Pharmaceutical Sciences and Medicine (IJPSM), Vol.6 Issue. 10, October- 2021, pg. 26-36

ISSN: 2519-9889

Impact Factor: 3.426

\begin{tabular}{|c|c|c|c|c|}
\hline S.No & Parameters & Limit & Observations & $\begin{array}{c}\text { Passes/ } \\
\text { Fail }\end{array}$ \\
\hline 1 & Specificity & $\begin{array}{l}\text { No Interferences at } \\
\text { retention time of the } \\
\text { Analytes peak. }\end{array}$ & $\begin{array}{l}\text { No Interference at } \\
\text { retentions time of } \\
\text { the analytes peak }\end{array}$ & Passes \\
\hline 2 & $\begin{array}{l}\text { System } \\
\text { Precision }\end{array}$ & RSD NMT $2.0 \%$ & $\begin{array}{l}\text { Azelnidipine: } 1.08 \\
\text { Telemisartan: } 1.22\end{array}$ & Passes \\
\hline 3 & $\begin{array}{l}\text { Method } \\
\text { Precision }\end{array}$ & RSD NMD $2.0 \%$ & $\begin{array}{l}\text { Azelnidipine:0.92 } \\
\text { Telemisartan: } 1.28\end{array}$ & Passes \\
\hline 4 & $\begin{array}{l}\text { Linearity of } \\
\text { detector } \\
\text { response }\end{array}$ & $\begin{array}{l}\text { Correlation coefficient } \\
\text { NLT } 0.999\end{array}$ & $\begin{array}{l}\text { Azelnidipine:0.9965 } \\
\text { Telemisartan:0.9907 }\end{array}$ & Passes \\
\hline 5 & Accuracy & $\begin{array}{l}\% \text { Recovery range 98- } \\
102 \%\end{array}$ & $\begin{array}{l}\text { Azelnidipine: } 101.033 \\
\text { Telemisartan:100.935 }\end{array}$ & Passes \\
\hline 6 & Ruggedness & $\begin{array}{l}\% \text { Recovery range 98- } \\
102 \%\end{array}$ & Within limits & Passes \\
\hline 7 & Robustness & RSD NMT $2.0 \%$ & Within limits & Passes \\
\hline 8 & $\begin{array}{l}\text { Limit } \\
\text { detection } \\
\text { (LOD) }\end{array}$ & $\begin{array}{l}\text { Based on SD of the } \\
\text { Response and slope }\end{array}$ & $\begin{array}{l}\text { Azelnidipine: } 2.225 \\
\text { Telemisartan:4.421 }\end{array}$ & Passes \\
\hline 9 & $\begin{array}{l}\text { Limit } \\
\text { Quantization } \\
\text { (LOQ) }\end{array}$ & $\begin{array}{l}\text { Based on SD of the } \\
\text { Response and slope }\end{array}$ & $\begin{array}{l}\text { Azelnidipine: } 6.742 \\
\text { Telemisartan: } 1.305\end{array}$ & Passes \\
\hline
\end{tabular}

Table 5: Summary of Validation Parameters 


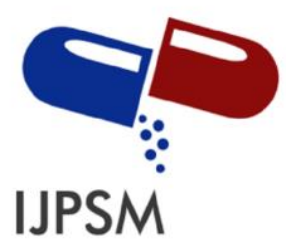

Silky Agrawal et al, Int. Journal of Pharmaceutical Sciences and Medicine (IJPSM), Vol.6 Issue. 10, October- 2021, pg. 26-36

ISSN: 2519-9889

Impact Factor: 3.426

\section{CONCLUSION:}

A RP-HPLC method has been developed for the simultaneous estimation of Azelnidipine and Telmisartan in pharmaceutical dosage forms, using UV detector. Different chromatographic conditions were used to develop the method. Elution was carried out with a mobile phase consisting Buffer (Potassium Phosphate, $\mathrm{pH} 4.0$ ): Methanol(60:40) at $\mathrm{pH} 4.0$, the flow rate was $1.0 \mathrm{ml} / \mathrm{min}$ at $215 \mathrm{~nm}$. The retention time for Azelnidipine and Telmisartan was found 5.69 and 3.44 minutes. Run time was found to be 7 minutes. It is evident from the study that the developed method is simple, specific, and precise and accurate. The solvents used are economic and easily available and hence the newly developed method can be used for routine analysis as method for the simultaneous estimation of Azelnidipinr and Telmisartan in pharmaceutical dosage forms.

\section{REFERENCES}

1. Walker R and Whittlesea C. Clinical Pharmacy and Therapeutics; 5thEdn; Elsevier (2007): 295-307.

2. Shewale VU., et al. "Azelnidipine: A Review on Therapeutic Role in Hypertension". Journal of Drug Delivery andTherapeutics 9 (2019): 1002-1005.

3. Chen B., et al. "Clinical use of azelnidipine in the treatment of hypertension in Chinese patients". Therapeutics andClinical Risk Management 11 (2015): 309-318.

4. Drug profile of "Azelnidipine" (2019)

5. "Azelnidipine" (2019).

6. Tamargo J and Ruilope LM. "Investigational calcium channel blockers for the treatment of hypertension”. ExpertOpinion on Investigational Drug (2016): 1-51.

7. Rele RV. "Spectrophotometric Estimation of Azelnidipine in Bulk drug and Pharmaceutical Dosage form by First Order Derivative and Area Under Curve Methods". American Journal of PharmTech Research 4.2 (2014): 126-135.

8. Rele RV. "Spectrophotometric estimation of azelnidipine in bulk and pharmaceutical dosage form by second order derivative method". Journal of Chemical and Pharmaceutical Research 6.8 (2014): 198-202.

9. Modi J., et al. "Stability Indicating Analytical Method Development and Validation for Estimation of Azelnidipine". World Journal of Pharmaceutical Research (2016): 831-847.

10. Patel N and Patel JK. "Simultaneous Determination of Azelnidipine and Olmesartan medoxomil by First Derivative Spectrophotometric Method". Scholar Research Library 4.4 (2012): 1080-1084.

11. Raskapur KD., et al. "UV-Spectrophotometric Method Development and Validation for Determinaton Of Azelnidipine In Pharmaceutical Dosage Form”. International Journal of 


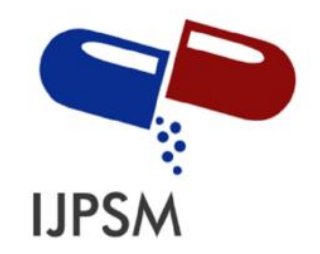

Silky Agrawal et al, Int. Journal of Pharmaceutical Sciences and Medicine (IJPSM), Vol.6 Issue. 10, October- 2021, pg. 26-36

ISSN: 2519-9889

Impact Factor: 3.426

Pharmacy and Pharmaceutical Sciences (2011): 238-240.

12. C Prabhakar., et al. "Method Development and Validation of Azelnidipine by RP-HPLC". International Journal of ChemTech Research 10.10 (2017): 418-423.

13. Amin AA., et al. "Simultaneous Determination of Azelnidipine and Olmesartan Medoxomil in Pharmaceutical Dosage Forms by UFLC Method". Journal of Pharma SciTech (2016): 69-74.

14. Gore MG and Dabhade PS. "Rp-Hplc Method Development and Validation of Azelnidipine”. IJPSR (2016): 5111-5114. 